\title{
ДЗЕРКАЛО АНАТОЛІї
}

(рецензія на монографію: Прушковська I. В. Незамкненість канону: поетика турецької драматургії / Ірина Віталївна Прушковська. - К.: Украӥнський письменник, 2015. - 390 с.)

Монографія Ірини Прушковської, присвячена турецькій драматургії другої половини XX - початку XXI ст., - цілісне дослідження, у якому відслідковується наступність у розвитку турецької драматургії в розрізі часу й культури. Так, у першому розділі розглянуто теоретичні питання, етапи розвитку турецької драматургії. Окрему увагу приділено розкриттю процесу переходу традиційного народного театру в авторську драму, впливу французької літератури на становлення сучасної турецької драматургії. Ірина Прушковська, пропонуючи власну періодизацію розвитку турецької драматургії, робить крок вперед на шляху вирішення дискутабельного у колах турецьких літературознавців питання, адже відштовхується від фактичного матеріалу і тенденцій розвитку драми, а не спирається суто на історичний грунт. Дослідниця зауважує, що проблематика і художні особливості турецької драми того часу зумовлені низкою як позалітературних (утвердження позицій ісламу на державному рівні, розбудова імперії й формування ідеології, намагання віднайти оптимальне співвідношення національної специфіки i впливу Заходу), так і літературних чинників (вихід за межі власне розважальної функції, закріплення амплуа за персонажами-масками, ускладнення композиційної парадигми народної драми).

Другий розділ монографії акцентує широку палітру виражальних засобів мистецьких явищ драматичної культури від буття класичних жанрів турецької драматургії до специфічних явищ мистецтва драми. Авторка розглядає жанрову парадигму сучасної турецької драматургії: аристотелівська драма, «відкрита» драма, історична та біографічна драми, віршована драма, монодрама, елементи «театру абсурду», дитяча драматургія, радіоп'єси.

Ірина Прушковська стверджує, що жанрова парадигма турецької драматургії формувалася під впливом кількох факторів, серед яких вирізняють: потужну традицію національного народного театру, а також ідейно-естетичні тенденції літературної доби; суспільно-політичну атмосферу в країні; вплив західної драми, що створило умови для співіснування різних жанрових форм та їх взаємовпливу.

У третьому розділі увагу дослідниці звернено на тематичну направленість турецької драматургії в іiі специфічності, що відтворює особливу картину світобачення турецьких авторів. Це топос міста, фемінні моделі творчості, деконструкція гендерних концептів, суфійський «текст», історичні переломні моменти тощо. Вартує прочитання матеріал про образи-символи (суфії-поети Мевляна і Юнус Емре), в яких сконцентровані уявлення про вчення суфіїв, втілення положень суфізму в практичному житті. Амбівалентним, полемічним 
постає у досліджених драматургічних текстах образ Роксолани, відомої в Туреччині як Гюррем Султана.

У четвертому розділі монографії здійснено детальний аналіз творчості видатних драматургів, представників різних напрямків у турецькій драматургії, яких об'єднує їх несхожість у сузір'ї самобутніх творців: Реджепа Більгінера, Мемета Байдура, Тунджера Джюдженоглу, Озена Юли, Неджаті Джумали. Так, симбіоз європейського і турецького художнього досвіду представлено у підрозділі 4.3. «Лінії творчості Озена Юли». Авторка зауважує, що твори О. Юли відіграють роль інтелектуальних провокацій як тематично (психічні розлади, гомосексуалізм), так i стилістично (абсурдистська поетика, експерименти 3 хронотопом, мовлення як ідентифікація персонажів, фрагментарність композиції, елементи міфопоетики, інтерпретація юнгівських архетипів), а саме: «Місце посередині світу», «Стамбул білий, горілка кольорова», «Хвилювання місяця», «Стомлені червоним», «Очі чорні як на Сході», «Несправжня Гюррем», «Здається квартира хазяїном», «Кохання далеко від домівки», «Стамбул - Софія», «Штутгартські діалоги і один монолог», «Облизуй, але не ковтай», «Важлива річ на Близькому Сході, яку треба зберегти». Неабиякий інтерес викликає підрозділ про творчість Т. Джюдженоглу, п’єси якого проникли й на українську сцену («Лавина», «Вертоліт»).

Кожен із розділів підкріплено перекладами драм українською мовою, здійсненими авторкою монографії. У науковий обіг вписано імена таких відомих турецьких драматургів, як У. Айваз, Б. Ак, О. Араїджи, Н. Ас'яли, М. Байдур, А. Байрамоглу, Ш. Гюрбюз, Е. Джанатан, Дж. Джанова, М. Бурак, Н. Джумали, Х. Еркек, 3. Качар, У. Кьоксал, М. Мунган, Т. Нар, Г. Дільмен, Т. Офлазоглу, Д. Сюмер, О. Юла, О. Асена.

У висновках простежується шлях драми від канонічного мислення до індивідуальних художніх форм у множинності рівнів засвоєння культури турецькою драмою. Авторка відтворює шлях зародження і розвитку авторської турецької драми, іiї генезу, зв'язок із традиціями національного театру (театру тіней, «Ортаоюну», меддахів), зародженням постмодерної драми і численних жанрових трансформацій у драмі XXI ст. (творчість Д. Джанови, Д. Сюмера, Ш. Гюрбюз, О. Юли, Е. Джанатана).

Ірина Прушковська окреслила основні жанри розвитку турецької авторської драми та визначити провідні тенденції у творчості чільних представників кожного з них, як-от: художня рецепція доісламської, оттоманської традицій із метою повернення до своїх витоків як реакція на надмірне захоплення західними зразками (Ш. Самі, Е. Тевфік), формування національного духу (М. Джевхер, А. Мітхат Ефенді, Н. Кемаль). Також проведене дослідження дало змогу: виявити акцент на опозиції «я - інший», проаналізувати форми (ремінісценції, адаптації, переклади) перенесення досвіду європейської драматургії (Брехт, Мольєр) на турецький грунт (А. Хайдар Бей, В. Паша, М. Шакір Фераізджізаде); проілюструвати інтертекстуальний характер турецької драми другої половини XX - початку XXI ст. (М. Байдур, Н. 
Джумали, М. Мунган), висвітлити особливості реципованого інтертексту (міфологія, турецька класична поезія, біографія, традиції, культура); осмислити турецьку постмодерну драму як культурну рефлексію, критичну переоцінку національної культури; схарактеризувати ключові образи турецької драматургії другої половини XX - початку XXI ст., їх зв'язок із релігійними і культурними традиціями, суфізмом), а також процеси деконструкції гендерних концептів, простежити роль суспільно-політичних факторів (подій 12 вересня 1980 р., загостренням тоталітаризму тощо) у розвитку жанру історико-біографічної драми.

Авторка дотримується аналітичного методу при формуванні основного матеріалу, іiі думки, аналіз і дослідження гармонують між собою, література, обрана як джерело дослідження, сучасна і змістовна (М. Анд, Дж. Кудрет, О. Нутку, С. Сіявушгіль, С. Шенер).

Безперечним позитивом монографії $є$ високий рівень літературознавчого аналізу, ретельне студіювання генези, еволюції й побутування турецької драматургії на іiі новітньому етапі. У цілому монографія Ірини Прушковської не має аналогів за цілісністю, комплексністю, творчим підходом до дослідження «запозичених» сюжетів та канонічних тем на різних рівнях сприйняття.

Хюсейн Озджан, доктор філологічних наук, професор, кафедра турещької мови і літератури університету «Фатіх» (Туреччина) 